\title{
The present-day Egyptian ivory trade
}

\author{
Esmond Martin
}

\begin{abstract}
There are probably more illegal ivory items for sale in Egypt than anywhere else in Africa. The author visited the main tourist centres of Cairo, Luxor and Aswan in late 1998 and counted over 21,000 ivory items for sale. Most of the ivory has come from elephants hunted illegally in Central and West Africa. Traders still transport the raw tusks, by truck and on camels, through Sudan across the desert into Egypt. Since the 1990 CITES ban on the international commercial ivory trade, Egypt, a member state, has prohibited not only the import and
\end{abstract}

export of ivory but domestic trade as well. Ivory sales continue openly, however, in the markets and hotels, and new ivory items are still being made. The main buyers are from France, Italy, Spain and Latin America. The Egyptian Government must enforce its legislation against this ivory trade to reduce the serious elephant poaching in the Central African Republic, the Democratic Republic of Congo and Sudan.

Keywords CITES, Egypt, ivory, smuggling, trade.

\section{Introduction}

The Egyptian ivory industry is probably the oldest in Africa and Egyptian artisans have a long tradition of working ivory. Even before the dynastic era, over 5000 years ago, Egyptian craftsmen were making elephant ivory combs, bangles and pendants (St Aubyn, 1987). It is likely that there has been uninterrupted commerce in ivory in Egypt since then. For centuries, Sudan has been the main supplier of raw ivory to Egyptian craftsmen and Sudanese traders are still providing the majority of tusks, which today are transported by motor vehicles and camel caravans.

Today, the display and sale of all ivory is illegal according to Egyptian regulations; however, ivory is still readily available in Cairo and other tourist centres. Indeed, while large, legal domestic ivory markets exist in southern and West Africa, there are probably more illegal elephant ivory products for retail sale in Egypt than in any other country in Africa. Despite the enormity of the problem, no surveys have been carried out and almost nothing has been published on the presentday Egyptian ivory trade.

I carried out a survey in November and December 1998 in the principal markets of Cairo, Luxor and Aswan, in order to obtain information relating to: the origin of the raw ivory; the people involved in the illicit movement of tusks into Egypt; the method of ivory transportation; the extent of the ivory processing operation; ivory retail markets; and the identity of the main buyers.

Esmond Martin (corresponding author) PO Box 15510 Mbagathi, Nairobi, Kenya. Tel: +2542891 185; fax: + 2542891007.

Received 22 April 1999. Accepted 7 September 1999

\section{Methods}

I visited almost all of the ivory retail outlets in Cairo, Luxor and Aswan and recorded the number and prices of ivory items on display. I also asked to see any pieces not on display and recorded the total number and price of these ivory items too. Where possible, information was gathered from the shop managers about the trade routes for tusks, the craftsmen who work the ivory and the nationalities of the customers (Plates 1-5).

\section{Results}

\section{Cairo}

The largest retail market in Egypt is the Khan al-Khalili in the mediaeval area of Cairo. It dates from the early 16 th century when Sultan al Ghuri ordered the destruction of the old Khan al-Khalili and the construction of a new one. Today, there are about 930 shops inside the Khan, making it one of the biggest markets in the Middle East (Seif, 1993; Logan et al., 1997). The retailers in Khan al-Khalili offer for sale 83 per cent of Cairo's ivory items (Table 1). The predominance of the Khan is logical because most foreign tourists visit this fascinating old market. In late 1998, a minimum total of 9619 elephant ivory items was on offer in at least 58 shops (excluding hawkers and street stalls) in the Khan, with 7 of the shops selling 69 per cent of the items. Most items were openly displayed for retail sale but some were kept in drawers. The figure of 9619 ivory items seen in the Khan is a minimum. This is partly because the shopkeepers probably possessed more ivory items than the author was shown and partly because there must have been additional pieces in the workshops that 
were situated above some of the shops. However, it makes economic sense for the shopkeepers to display most of their carved ivory and I estimate that I saw at least 80 per cent of all ivory items for retail sale in the Khan al-Khalili.

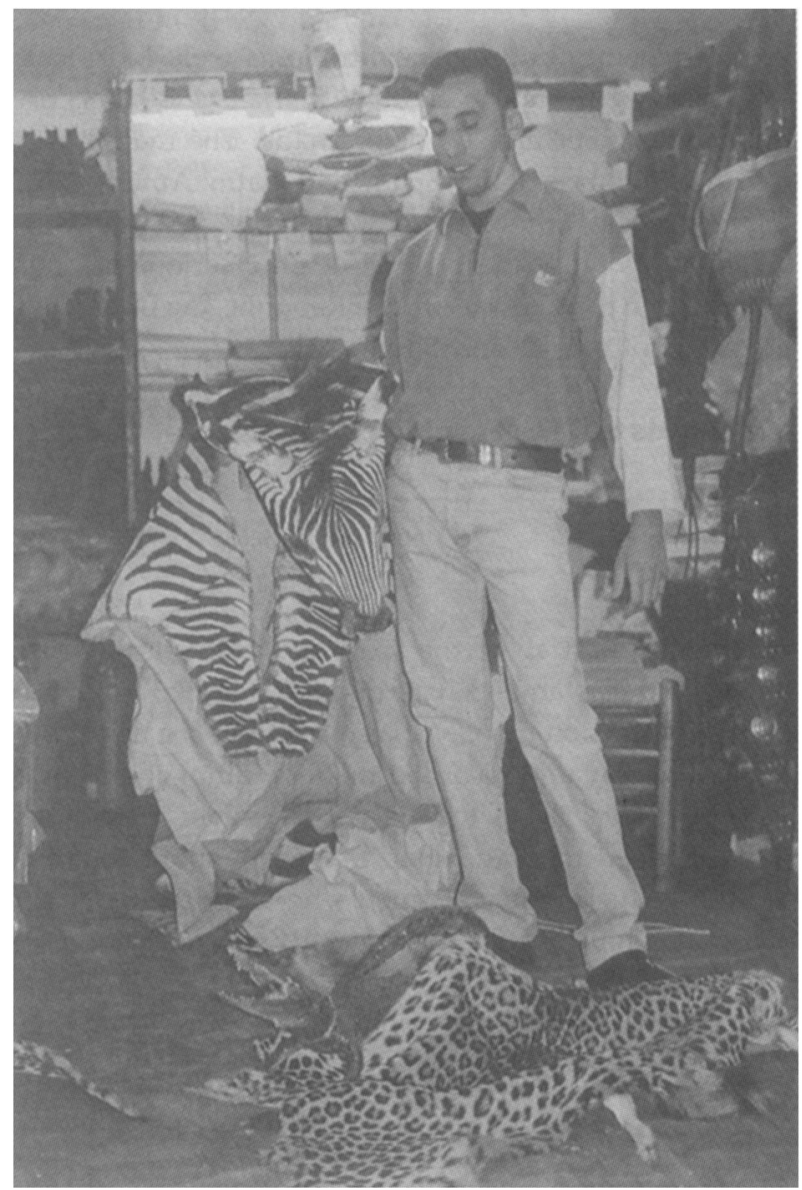

Plate 1 In addition to raw ivory, traders from Sudan supply zebra and leopard skins to souvenir shops in Cairo (Esmond Martin).

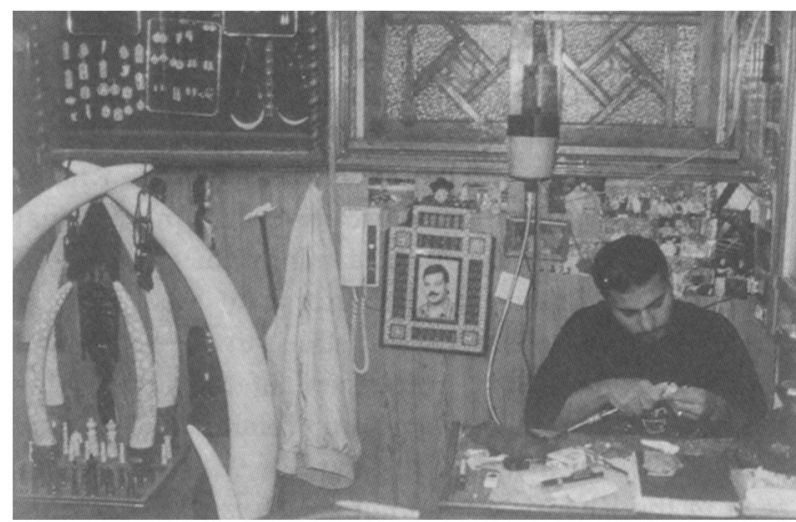

Plate 2 Almost all ivory craftsmen in Egypt now work in the Cairo area. Egyptians have been carving ivory for several thousand years (Esmond Martin).

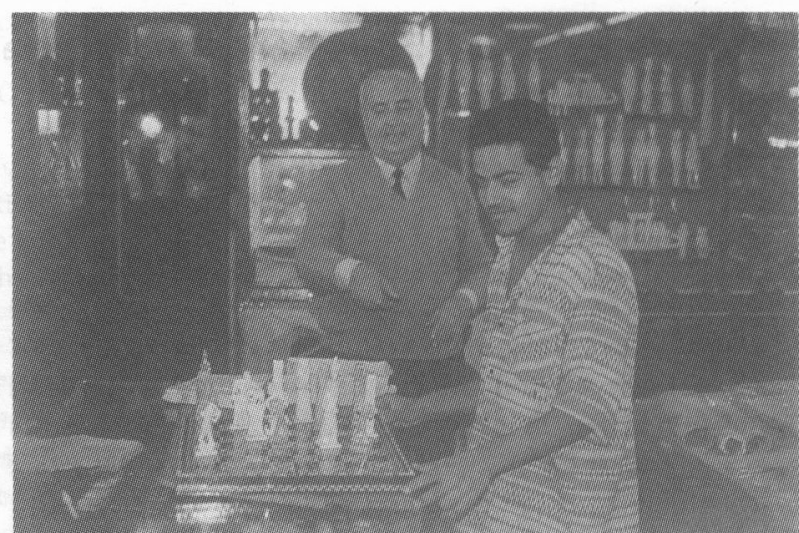

Plate 3 Ivory chess sets, despite being fairly bulky and thus more difficult to conceal in personal luggage, are still being smuggled from Egypt into European countries (Esmond Martin).

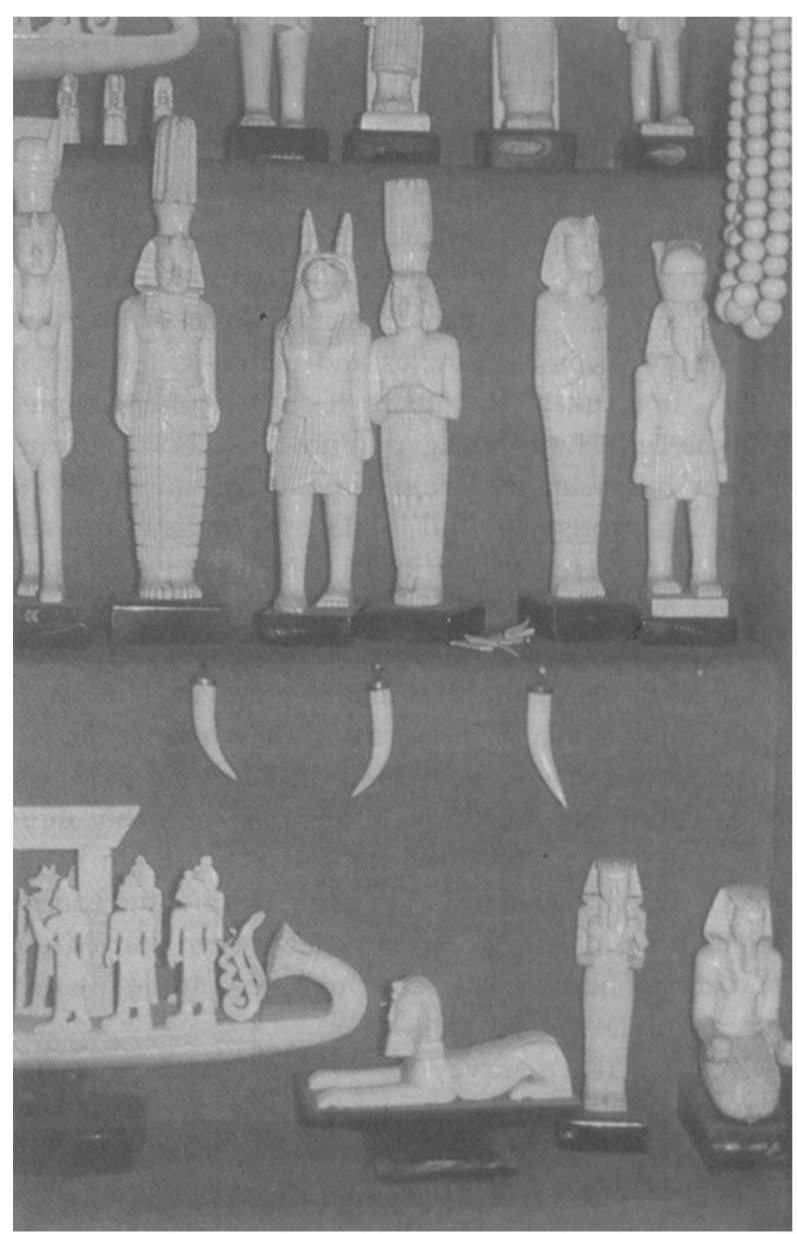

Plate 4 Small statues of Pharaohs and their queens are popular, especially with southern European buyers (Esmond Martin).

Shops selling similar items tend to be grouped together in the Khan al-Khalili. The main ivory outletsthe souvenir and jewellery stores-are generally located in the central section and vary in size, with a few large stores but most being very small. The number 


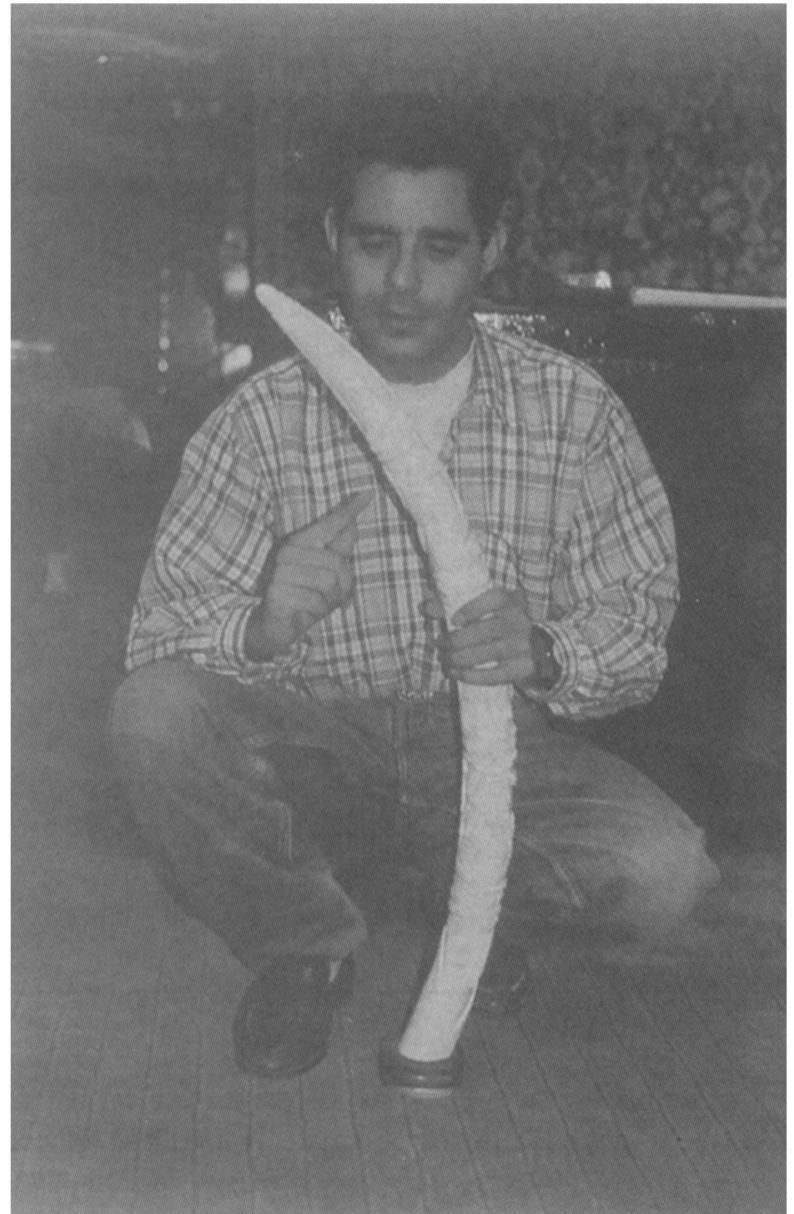

Plate 5 Tusks, originating mostly from Central African Republic, Democratic Republic of Congo and Sudan, are sometimes carved whole and sold in Cairo (Esmond Martin).

of ivory commodities per shop ranged from 1 to 2235 (the largest number seen in Egypt), with an average of 166 pieces per retail outlet. The most common ivory items for sale were sculptures/figurines (65 per cent of the total) followed by scarabs (15 per cent), jewellery (10 per cent), raw and carved tusks ( 3 per cent) and other pieces ( 7 per cent). Where there are large quantities of ivory items for sale, the shopkeepers sometimes also specialize in camel bone and wood. Where only a few ivory pieces are displayed, the retail outlets also sell other typical Egyptian souvenirs, especially jewellery. Jewellery shops often sell good quality ivory pieces, which are sometimes used to separate jewellery displays on the shelves.

Ivory is also sold in the luxury hotels frequented by foreign tourists. Ninety-nine per cent of all the ivory items seen for sale in Cairo are found in the Khan and in the luxury hotels (Table 1). Ivory items found in the hotels are more expensive than those in the Khan al-Khalili. In one five-star hotel, a bird carving, $17.5 \mathrm{~cm}$ tall, was on sale for $\$ U S 2200$, while a $30-\mathrm{cm}$ sphinx was offered for $\$ U S 8000$, after bargaining. The two items were well made compared with other sculptures commonly seen, but the prices were much higher than those found elsewhere in Cairo (Table 2). Some hotel shops sell camel bone items as well as ivory and, although the majority of shop owners are honest, some tourists have been misled into buying camel bone pieces, thinking they are ivory. Very few ivory items are found in the modern downtown shopping areas of Cairo because Egyptians seldom buy ivory. It is not considered fashionable and is relatively expensive when compared with the earnings of most employed people, which is typically less than US\$100 a month.

Ivory workshops are located above some of the retail outlets in the Khan, but the increase in numbers of foreign tourists visiting the market has caused rents to rise. As a result, some of the workshops have given up their space to retail shops and moved out of the Khan

Table 1 Number of elephant ivory items for sale in Egypt in November and December 1998

\begin{tabular}{lrrr}
\hline Place & No. of shops with ivory & No. of ivory items seen & Per cent of ivory items \\
\hline Cairo & 88 & 11,627 & 54 (of total) \\
$\quad$ Khan al-Khalili & 58 & 9619 & 83 \\
Hotels & 25 & 1869 & 16 \\
Elsewhere & 5 & 139 & 1 \\
Luxor & 33 & 6445 & 30 (of total) \\
Old market & 7 & 125 & 2 \\
Hotels & 11 & 1780 & 28 \\
Elsewhere (near hotels) & 15 & 4540 & 70 \\
Aswan & 21 & 3388 & 16 (of total) \\
$\quad$ Market/corniche & 15 & 3090 & 91 \\
Hotels & 3 & 105 & 3 \\
$\quad$ Elsewhere & 3 & 193 & 6 \\
Totals & 142 & 21,460 & 100 (of total) \\
\hline
\end{tabular}

Source: Survey carried out by E. Martin. 
Table 2 Average retail prices for Egyptian-made ivory items in Cairo, Luxor and Aswan in late 1998

\begin{tabular}{|c|c|c|c|}
\hline Item type & Item & Size $(\mathrm{cm})$ & Price (\$US prior to bargaining) \\
\hline General & $\begin{array}{l}\text { Chess set (all ivory) } \\
\text { Shoe horn with elephant carvings } \\
\text { Paper knife }\end{array}$ & $\begin{array}{l}\text { Medium } \\
15-18 \\
13\end{array}$ & $\begin{array}{r}1021 \\
69 \\
35\end{array}$ \\
\hline Walking sticks & $\begin{array}{l}\text { Full ivory } \\
\text { Ebony with ivory handles }\end{array}$ & $\begin{array}{l}91 \\
91\end{array}$ & $\begin{array}{r}203 \\
84\end{array}$ \\
\hline Ornaments & $\begin{array}{l}\text { Carved tusk } \\
\text { Boat (with figures) } \\
\text { Crocodile } \\
\text { Elephant } \\
\text { Elephant bridge } \\
\text { Pharaoh (large) } \\
\text { Pharaoh (small) } \\
\text { Bird } \\
\text { Rhino } \\
\text { Sphinx } \\
\text { Obelisk } \\
\text { Lion } \\
\text { Scarab }\end{array}$ & $\begin{array}{r}76-91 \\
20-36 \\
36-46 \\
8-10 \\
13-30 \\
18-25 \\
6-10 \\
8-10 \\
6 \\
5-10 \\
5 \\
8-13 \\
2.25-4\end{array}$ & $\begin{array}{r}847 \\
632 \\
439 \\
321 \\
244 \\
242 \\
46 \\
84 \\
52 \\
48 \\
44 \\
44 \\
12\end{array}$ \\
\hline Jewellery & $\begin{array}{l}\text { Necklace (beaded) } \\
\text { Necklace (beaded) } \\
\text { Necklace (beaded) } \\
\text { Bangle } \\
\text { Ring }\end{array}$ & $\begin{array}{l}\text { Large } \\
\text { Medium } \\
\text { Small } \\
1-4 \text { wide } \\
\text { Very small }\end{array}$ & $\begin{array}{r}176 \\
66 \\
22 \\
44 \\
2\end{array}$ \\
\hline
\end{tabular}

Source: Survey carried out by E. Martin.

to cheaper premises. It is not possible to give a precise number of people who work ivory in Cairo; however, the owners of the principal workshops in the Khan estimate that about a 100 people work in the trade either full- or part-time, with over half of them crafting camel bone and wood as well. In the Khan itself, there are several small workshops where between one and four artisans process ivory exclusively, but most ivory craftsmen now work from their homes. The craftsmen use both hand tools and electric drills, but the quality of the workmanship, especially the finish compared with Zimbabwean or South African work, is mediocre to poor. The Egyptian artisans are both Muslims and Christians, some of the latter having come from Asyut, a city located between Cairo and Luxor that has long been noted for its ivory workers. Ivory craftsmen are generally paid piece-rate and do not receive wages. At present, they produce small items such as scarabs, jewellery, knives and figurines, which can be smuggled easily out of Egypt by foreign tourists, who are the main customers. The artisans can earn about LE500 (\$US147) a month, considerably more than government salaries and roughly equal to the earnings of a young English-speaking secretary in the private sector.

In addition to locally made ivory items, which make up 98 per cent of total ivory sales, some shops in the Khan al-Khalili sell the typical ivory female figures carved in Central and West Africa, as well as various pieces from Sudan. There is also trade in carved or polished tusks, many quite small, from these places. Today, there are very few ivory pieces for sale that have been imported from Asia. Although Hong Kong statistics show that from 1979 to 1988 worked ivory worth a total of $\$ U S 26,509$ was exported wholesale to Egypt (Milliken \& Melville, 1989), almost none of this remains in the shops. Some traders admit to purchasing pieces from India in the recent past, but now only a few bangles remain.

\section{Luxor}

In Luxor, I found at least 33 shops selling a minimum total of 6445 pieces of ivory. Two jewellery stores on Khaled ibn el Walid street in the southern part of the city, where several of the five star hotels are located, each displayed over 1100 items. One of these offered 39 polished tusks, most weighing $1.5-2 \mathrm{~kg}$. There were also 48 carved tusks, again many being small in size. The majority of pieces for sale were figurines, scarabs and jewellery. Almost the entire economy of Luxor is based on foreign tourists.

Luxor is the second most important centre, after Cairo, for working and selling ivory; however, since the international ivory ban in 1990, the number of people carving ivory in Luxor has dropped to probably less than a dozen. Today, Luxor is noted for its small 
workshops with craftsmen using alabaster, sandstone, limestone, marble, wood and papyrus. In the 1980s, Asyut was more important than Luxor for ivory craftsmen, but it is now of little significance because most of the former ivory craftsmen have switched to camel bone. Very few tourists visit Asyut because of the threat from Muslim extremists (it was not safe for the author to visit the city) and the lack of tourist attractions. Therefore, all of the handicrafts and works of art made there are sent to the main tourist centres of Cairo, Luxor, Aswan and the resorts of the Red Sea. There is very little ivory in Alexandria because, apart from people from the Arabian Gulf states, few tourists visit that city.

\section{Aswan}

Fewer foreign tourists visit Aswan than Luxor and there are consequently fewer pieces of ivory available. I found 21 shops with c. 3400 pieces of ivory for sale. Ninetyone per cent of these are on the corniche (the boulevard along the Nile) and immediately behind this road in the
Sharia as-Souk, which is the tourist market. At present, the people of Aswan are not working ivory because those people making handicrafts and works of art are Nubians, who do not have a recent tradition of using ivory. However, some tusks do pass through Aswan because one of the major camel markets for Sudanese animals is just north of Aswan at Daraw (Fig. 1).

\section{Routes used to smuggle tusks into Egypt}

Most of the raw ivory smuggled into Egypt comes via Sudan, according to traders interviewed in Egypt and Sudan (Martin, 1998). Either camels or vehicles are used to transport the tusks. There are two main camel caravan routes: one on the eastern and the other on the western side of the Nile. The Rashayda, who live on the Red Sea coast and moved into Sudan from Saudi Arabia in the 18th century, are notorious smugglers of electronic goods and other consumer items by dhow from Saudi Arabia to Sudan. They are also famous camel herders who move large numbers of camels from
Fig. 1 Map of Egypt and surrounding areas showing places mentioned in the text.

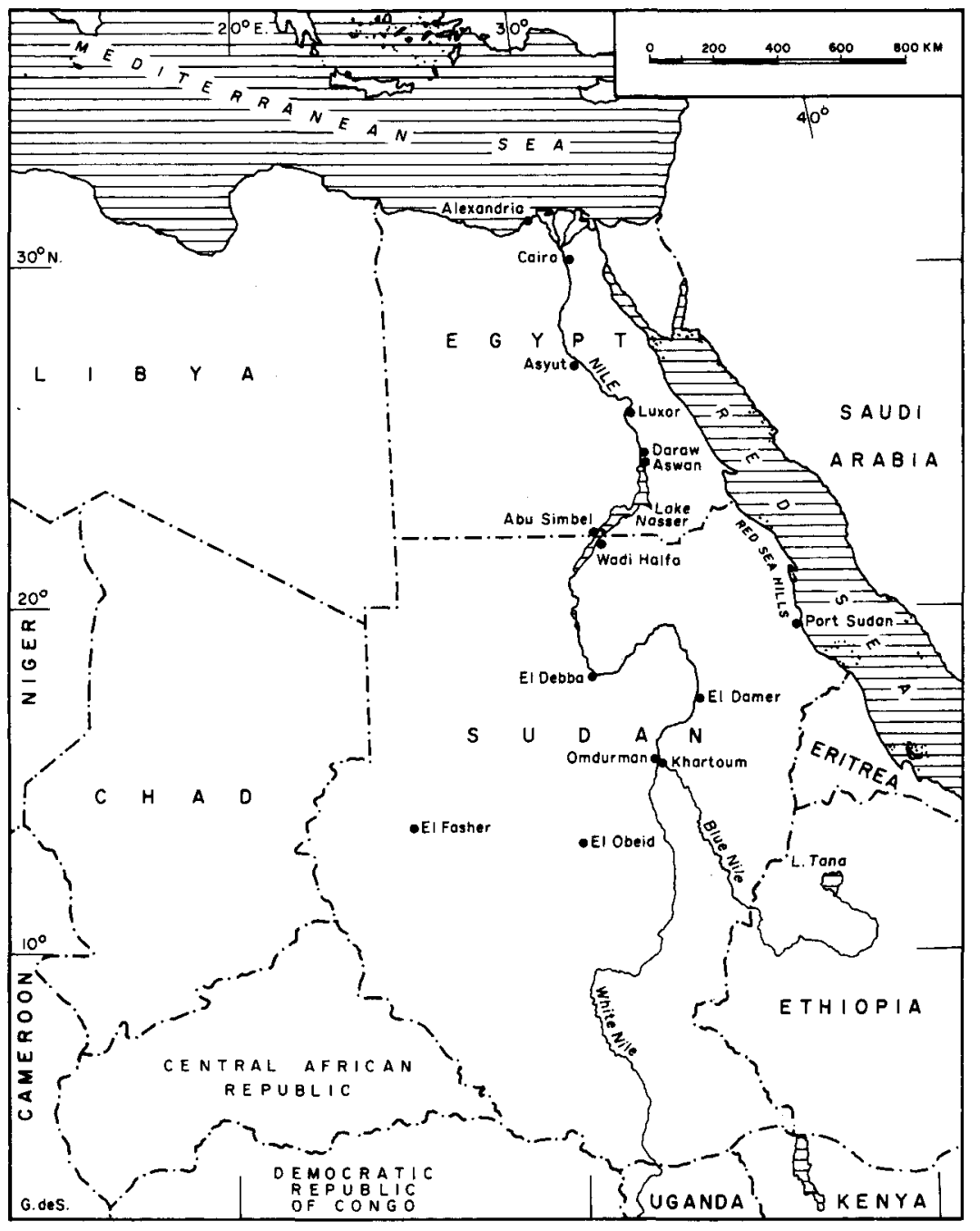


near Port Sudan or El Damer on the Nile to southern Egypt (Fig. 1). The caravans are divided into groups of about 100 camels (called risallas) to avoid depleting wells and pastures (Chittock, 1996). Each risalla has several herders who might carry cigarettes, electronic appliances and other goods from Saudi Arabia for smuggling into Egypt. Some of these herders may also carry raw ivory. They move northwards through the Red Sea hills and try to cross the border into Egypt at night in order to avoid detection by the Egyptian authorities (M. Asher, pers. comm., 1998). They sell their camels and other goods-occasionally including ivory - at either Abu Simbel or Daraw. The main aim of these journeys is to sell the animals for meat (they are usually taken by truck to Cairo, which has the largest camel market in the world) rather than to transport goods. Occasionally, the Rashayda smuggle goods, including small amounts of ivory, into Egypt using four-wheel-drive vehicles and trucks, following a similar route to that used by the camels: they are well armed and willing to fight if necessary (M. Asher, pers. comm., 1998).

Camel caravans also start their journey from the western side of Sudan, which is the beginning of the ' 40 days road', so named because this is the approximate time required for the journey by camel from western Sudan to southern Egypt. This route is much more important for smuggling ivory than is the eastern one. Many of these caravans begin the journey in El Fasher, which is the capital of Darfur. The herders come from many tribes but especially the Baggara, who have connections with the Central African Republic (CAR) and southern Sudan. Some Baggara have travelled to the eastern side of CAR to kill elephants (M. Asher, pers. comm., 1999). Unlike the Rashayda, these tribesmen do not possess smuggled manufactured goods from Saudi Arabia because they have no access to them; instead, they carry natural products such as ostrich feathers, wild animal skins and sometimes ivory. They move the camels and their illicit goods from El Fasher north-east to the Nile around El Debba and then down the Nile, past Wadi Halfa, into southern Egypt to the camel markets in Abu Simbel and Daraw (M. Asher, pers. comm., 1998). In addition to the camel caravans on the ' 40 days road', West Africans, especially Nigerians according to ivory traders in Cairo, transport ivory across western Sudan by truck to Wadi Halfa and then by ferry across Lake Nasser to Aswan, ending up in Cairo in the Khan al-Khalili. I saw several of these West Africans attempting to sell raw tusks to the ivory merchants in the Khan. There are also some traders from El Fasher, El Obeid and Omdurman who carry mostly rock salt but also a small amount of ivory by truck to upper Egypt.

\section{Prices for raw tusks}

Most of the raw ivory pieces sold by the importers or their agents to the craftsmen or workshop owners in Cairo are small tusks weighing $1-4 \mathrm{~kg}$. The price per $\mathrm{kg}$ averages LE210 (\$US61.55), compared with LE117.50 (US\$34.44) for very small pieces and tiny remnants from the making of figurines. On average, mediumsized tusks weighing $5-11 \mathrm{~kg}$ are bought by Cairo merchants and craftsmen for LE267.8 (\$US78.49) per kg, while pieces above $12 \mathrm{~kg}$ sell for about LE400 (\$US117.23) per $\mathrm{kg}$. Wholesale prices per $\mathrm{kg}$ vary between dealers from LE321 (\$US93.96) for small pieces $(1-4 \mathrm{~kg}$ ) to LE350 (\$US102.58) for pieces weighing 5-10 $\mathrm{kg}$, and up to LE800 (\$US237.47) for large tusks weighing $20 \mathrm{~kg}$.

The export from Sudan to Egypt of small tusks from female and juvenile elephants is not a new phenomenon. Egyptian craftsmen have had to become accustomed to working these small tusks, which are also of generally poor quality: they tend to be brittle and cracked as a result of the low humidity and high temperatures in northern Sudan (I. Parker, pers. comm., 1999). This may help to explain why the quality of Egyptian carving is sometimes poor.

\section{Analysis of the ivory market in Egypt}

The prices that the merchants and craftsmen pay for raw ivory in Cairo are roughly double those paid in Omdurman in Sudan (Martin, 1998) because of transport expenses and the need to avoid the authorities when crossing the border. These two factors have to be taken into account when assessing the final costs of raw ivory in Egypt.

There is a main difference between customers for ivory products in Sudan and in Egypt. In Sudan, where there are scarcely any foreign tourists, eastern Asian labourers and businessmen are the main customers. The main buyers are some of the 5000 or so Chinese (who are working on the oil pipeline, the new bridge in Khartoum and on the roads), together with c. 500 Malaysian middle-level managers and the 200 or so South Koreans involved in business, including hotels. There were few of these eastern Asians in Sudan in the 1980 s and numbers have been steadily rising since the early 1990s.

In Egypt, the main customers for ivory commodities are some of the foreign tourists, who numbered close to 4 million in 1997. The principal buyers are from France, Italy, Spain and Latin America, according to the shopkeepers. Visitors from the Arabian Gulf states purchase walking sticks and a few other items but the Egyptians buy almost nothing. When the international trade in 
elephant ivory was legal in the 1980s and when demand in America, Europe and Japan was high, the Egyptian ivory industry flourished. When ivory imports were banned by the USA and western European countries in 1989, and following the CITES ban of 1990, which prohibited all commercial imports and exports of elephant ivory for member states, Egypt's ivory business declined because of reduced demand. The number of craftsmen decreased, with many of them now carving camel bone and wood. In fact, the number of new ivory pieces being made has decreased quite considerably and most of the ivory items still seen in the shops were made prior to the 1990 CITES ban.

Accurate statistics of annual ivory sales in Egypt are not available because the managers of shops selling ivory are unwilling to provide the information in order to avoid taxation. However, in a luxurious hotel in Cairo, one shopkeeper with 227 pieces of ivory for sale (almost all of them sculptures) admitted that in 1988 he had sold about 20 pieces and by 1997 only 8 pieces. In 1998 , he sold only four pieces, possibly as a result of a reduction in the number of foreign visitors following the killing of tourists in Luxor in November 1997. Despite the overall loss of business (the number of tourists visiting upper Egypt fell by c. 50 per cent in 1998), shopkeepers still find it worthwhile to display ivory in many of the most luxurious hotels and in the Khan al-Khalili.

Although exact figures for the annual turnover of ivory are unavailable, estimates can be made of the total weight and value of the items seen in Cairo, Luxor and Aswan. Assuming a minimum of 21,640 pieces with an average weight of $40 \mathrm{~g}$ each, based partly on the best-selling figurines (whose weight and price are about average for the items in the shops), there are at least $858.4 \mathrm{~kg}$ of ivory commodities on the market (mostly pre-1990 stock). Assuming an average price of LE250 (\$US73.27) per piece, based on the price for a typical Egyptian statue, the total retail value is at least \$US1,572,392.

\section{The legal position of the ivory trade}

Egypt has been a member of CITES since 1978 and has not taken out a reservation to allow for international trade in ivory. Thus, all commercial imports and exports have been illegal since early 1990. The Egyptian constitution states that all international conventions to which Egypt is a party have the same power in law in Egypt. Furthermore, Law No. 4 of 1994 of the Egyptian Government makes the Egyptian Environmental Affairs Agency responsible for international wildlife conventions and may be interpreted as including CITES and CITES-listed species, but these are not specifically men- tioned. The provisions of this law apply to species listed in the Executive Regulations of the law (issued as Prime Minister's Decree No. 338 of 1995) but do not specifically mention the African elephant. However, the Executive Regulations apply to "any other fauna determined by International Conventions to which the Arab Republic of Egypt is a Party'. By extension, this would include elephants and all CITES-listed species, thereby making import, export and domestic sale contrary to the law. Under Law No. 4, the penalty for possession, transport, sale or the offer for sale of species included under the Executive Regulations is a fine of LE2005000 (\$US58.65-1466) and confiscation of the specimens. There is no provision for imprisonment for offences against this law. The only other relevant law is Act No. 53 of the Egyptian Government on Agriculture, for which Ministerial Decrees listing protected species have been drafted. This has been the basis for implementing CITES, albeit to a limited degree, prior to Law No. 4 of 1994

Egyptian Government officials and prominent conservationists within the country interpret Law No. 4 as prohibiting all domestic and international trade in elephant ivory in Egypt (Hoath, 1990; A. Shehata, General Manager, National Parks of Egypt Protectorates Development Programmes, pers. comm., 1998; M. Fouda, Chief Adviser, Nature Conservation Sector, Egyptian Environmental Affairs Agency (EEAA), pers. comm., 1999). However, the wildlife laws of Egypt are confusing and inadequate. At the Tenth Meeting of the Conference of the Parties to CITES in 1997, the CITES Secretariat included Egypt in a list of seven countries that had not developed national legislation for the implementation of CITES and for which substantial levels of trade in wild species were believed to occur (Gray, 1997).

Despite the fact that trade in ivory is prohibited in Egypt, the government has done very little to enforce the law. None of the shopkeepers interviewed showed concern about being arrested and/or having ivory products seized. On the other hand, in late 1996, the Egyptian authorities raided the Kerdasa market, on the outskirts of Cairo, and confiscated hundreds of fox and jackal skins, dorcas gazelle hides and other Egyptian wildlife items (Hoath, 1997). In early 1997, the environmental police and officials from the EEAA inspected the Tunsi market in Cairo and confiscated many live birds, snakes, lizards and tortoises (Hoath, 1997). It is not clear why the Egyptian authorities permit the commerce in ivory to continue; perhaps there have been few complaints and little political pressure put on officials to close down trade in a non-Egyptian wildlife product that has a long tradition in the country. 


\section{Conclusion}

The ivory trade in Egypt is older than in any other country in Africa and perhaps in the world. There has probably been continuous commerce in the raw product in Egypt for over 5000 years. For centuries, Sudan has been the major source of tusks, and camels remain one of the principal means of transporting them into Egypt. Today, Egyptian markets, especially the Khan al-Khalili in Cairo, probably have more illegal ivory items for sale than anywhere else on the continent. The long tradition of ivory working in Egypt and the relative ease of smuggling tusks through Sudan means that there will be major difficulties in reducing significantly and eventually eliminating this illegal commerce.

Economic collapse and the breakdown of law and order in Central African countries have aggravated the situation. The fall in the standard of living experienced by most Sudanese in the past 10 years (EIU, 1998) may increase economic incentives to take animal products into Egypt in the future. Furthermore, in the last few years, Sudanese poachers have moved increasingly into neighbouring countries such as the Democratic Republic of Congo and the CAR to kill elephants. Congolese and Sudanese poachers have entered Garamba National Park in the Democratic Republic of Congo to kill elephants for meat and for their tusks, both of which have been transported to various countries. According to reports from the park's personnel, c. 75 per cent of all poachers entering Garamba Park from 1996 to 1998 were Sudanese, who were well armed with automatic rifles (A. K. K. Hillman Smith, pers. comm., 1999). As a result of poaching, Garamba's elephant population declined from an estimated 11,175 in 1995 to 5487 in 1998 (Hillman Smith, 1998); it is extremely likely that some of the tusks have ended up in Egypt.

There are various ways to reduce the ivory trade in Egypt. The government needs to enforce national regulations banning internal sales of ivory. A major effort is also required by the government to clear the ivory from the shops and to inform foreign tourists that the sale of ivory in Egypt and the export of ivory from Egypt and import into their home countries is against the law. The government also needs to publicize the penalties for those breaking the law. Furthermore, tourists should be better educated by conservation organizations in their home countries concerning the effect that purchasing ivory has on elephant populations. Trade bans alone do not usually work unless demand for the commodity is reduced significantly. If ivory were to become less fashionable internationally, especially in Mediterranean countries and Latin America, the price would fall and this would make the crafting and sale of ivory less profitable for shopkeepers in Egypt.

\section{Acknowledgements}

The author wishes to thank Global Communications for Conservation, the Columbus Zoological Park Association, and Friends of Howletts and Port Lympne for funding this study in Egypt in November and December 1998. Thanks are also due to Greg Overton for his helpful remarks concerning the manuscript, and for the comments of two anonymous referees.

N.B. Since this article went to press, the Egyptian Government issued 'Ministerial Decree No. 1150 for the year of 1999', which provides legislation for the implementation of CITES. This decree was published in the Official Journal of Egypt on 18 September 1999.

\section{References}

Chittock, L. (1996) Shadows in the Sand. Following the Forty Days Road, 8. Camel Caravan Press, Cairo.

EIU (The Economist Intelligence Unit) (1998) Country Profile: Sudan, 18. The Economist Intelligence Unit, London.

Gray, J. (ed.) (1997) Report on the Tenth Meeting of the Conference of the Parties to CITES. TRAFFIC Bulletin, 17, 7.

Hillman Smith, A.K.K. (1998) The current status of the northern white rhino in Garamba. Pachyderm, 25, 104-105.

Hoath, R. (1990) The Ivory Nile. BBC Wildlife, 8(10), 700. Hoath, R. (1997) Eco-police finally bust the bazaars. $B B C$ Wildlife, 15(4), 52.

Logan, L., Cole, G., Simonis, D. \& Wayne, S. (1997) Egypt: A Lonely Planet Travel Survival Kit, pp. 169-170. Lonely Planet Publications, Hawthorn, Australia.

Martin, E. (1998) New buyers of ivory in the Sudan threaten elephants. Oryx, 32, 166-169.

Milliken, T. \& Melville, D. (1989) The Hong Kong ivory trade, 89. Draft Report to the Second Meeting of the CITES African Elephant Working Group. Unpublished report, TRAFFIC International, Cambridge, UK.

Seif, O. (1993) Khan al-Khalili: A Comprehensive Mapped Guide to Cairo's Historic Bazaar, 6. The American University in Cairo Press, Cairo.

St Aubyn, F. (ed.) (1987) Ivory: An International History and Illustrated Survey, 35. Harry N. Abrams, New York.

\section{Biographical sketch}

Esmond Martin, a geographer, has been studying the wildlife trade of Africa and Asia for over 25 years. He has worked closely with World Wide Fund for Nature, IUCN-The World Conservation Union and TRAFFIC. He specializes in investigating trade in rhino horn and elephant ivory. He has published over 150 articles on the subject. Dr Martin lives in Nairobi, Kenya. 